\title{
Analisis Faktor yang Berpengaruh pada Kecenderungan Kecurangan Akuntansi (Fraud): Studi pada LPD Kecamatan Tabanan
}

\author{
Putu Dian Pradnyanitasari, Ni Made Intan Priliandani, I Ketut Puja Wirya Sanjaya \\ Universitas Warmadewa, Fakultas Ekonomi dan Bisnis \\ Jalan Terompog No. 24, Sumerta Kelod, Kec. Denpasar Timur, Bali 80239 \\ E-mail: dianpradnya@gmail.com, intanpriliandani88@gmail.com,pujaws@gmail.com
}

\begin{abstract}
Abstrak
Tujuan dilakukannya penulisan ini adalah menguji pengaruh kesesuaian kompensasi, pengendalian internal kas dan moralitas individu pada kecenderungan kecurangan akuntansi (fraud). Terdapat 36 responden yang merupakan pekerja di LPD Kabupaten Tabanan dengan menggunakan purposive sampling dan analisis regresi linier berganda digunakan untuk menjawab hipotesis penelitian. Penelitian memperoleh hasil semua faktor yang diuji memiliki pengaruh negative terhadap kecenderungan kecurangan akuntansi (fraud).
\end{abstract}

Kata Kunci: Pengendalian Intern Kas, Kesesuaian Kompensasi, Moralitas Individu, Kecenderungan Kecurangan Akuntansi

\begin{abstract}
The purpose of this paper is to examine the influence of the suitability of compensation, internal control of cash and individual morality to the tendency of the accounting fraud (fraud). There were 36 respondents who were workers in LPD Tabanan Regency using purposive sampling and multiple linear regression analysis was used to answer the research hypothesis. The study found that all the factors tested had a negative effect on the tendency of accounting fraud (fraud).
\end{abstract}

Keywords: Internal Cash Control, Compensation Suitability, Individual Morality, Tendency of Accounting Fraud

\section{Pendahuluan}

Fraud dapat didefinisikan sebagai kecurangan, dimana kondisi ini dapat pada setiap sector baik pemerintahan maupun swasta. Tindakan fraud dapat memberikan keunggulan pada pihak yang melakukannya, dan tentunya akan memberikan efek buruk pada rusaknya reputasi usaha, organisasi serta kerugian dan kerusakan moral pihak yang terkait. Seseorang melakukan fraud cenderung disebabkan karena adanya kesempatan untuk melakukan fraud dan faktor individu lainnya. Kecurangan yang sering terjadi diantaranya adanya hal yang menyimpang dalam penyampaian laporan keuangan dengan menyajikan laporan yang tidak handal dan relevan. Indikasi ini dapat dilakukan dengan membuat ayat jurnal yang salah serta tidak terdapatnya penyesuaian otorisasi dari pihak manajemen dengan rincian serta penjelasan pendukung maupun pengeluaran yang tidak didukung oleh dokomen pendukung, faktur yang dibuat ganda, penghancuran dan perusakan dokumen asli. Tindakan penyimpangan ini merupakan salah satu tindakan kecurangan akuntansi.

Lembaga Perkreditan Desa (LPD) sebagai satu organisasi keuangan yang dibentuk dari kegiatan organisasi masyarakat atas dasar aktifitas kegiatan ekonomi masyarakat di Bali yaitu sekaa. Kegiatan yang biasanya dilakukan oleh LPD adalah menghimpun serta menyalurkan dana untuk anggota dari kelompok tersebut. Hasil yang dicapai oleh keberhasilan pengelolaan LPD yang baik maka akan semakin kokohnya adat dan budaya suatu desa. Sebagai organisasi atau lembaga di bidang keuangan LPD dapat menghimpun dan menyalurkan dana kepada masyarakat. Hal inilah yang menyebabkan LPD sebaiknya menggunakan system pengendalian internal yang baik. Pencegahan yang bisa dilakukan untuk meminimalisasi adanya kecurangan akuntansi (Fraud) adalah dengan dirancangnya suatu sistem pengendalian internal yang efektif. Wilopo (2006) 
mengungkapkan dengan keefektifitasan dalam melakukan pengendalian intern akan mampu meminimalisasi kecenderungan kecurangan akuntansi.

Pengendalian kas adalah hal yang penting bagi perusahaan. Hal ini karena kas merupakan harta suatu perusahaan yang likuid dan relatif besar jumlahnya. Berdasarkan hal tersebut maka kas dari suatu perusahaan harus dijamin keamanannya. Pengendalian intern pada tulisan ini akan berfokus pada pengendalian intern kas. Kas merupakan alat transaksi yang hampir selalu ada di setiap transaksi selain itu kas bersifat mudah untuk dipindahtangankan dan dimanipulasi.

Selain itu Thoyibatun (2009) mengungkapkan bahwa kecenderungan kecurangan akuntansi dapat berpengaruh pada kesesuain kompensasi. Kompensasi berkaitan erat dengan penghargaan, dimana sangat berkaitan dengan reward kepada karyawan atas jasa ataupun prestasi yang telah meningkatkan reputasi organisasi. Dengan kompensasi yang adil maka diharapkan setiap karyawan merasa puas atas reward yang diperoleh dan menyebabkan berkurangnya Tindakan yang berkaitan dengan kecurangan akuntansi yang dapat menguntungakan diri pribadi mereka.

Tindakan penyelewengan atau kecurangan akuntansi berhubungan dengan etika. Seseorang dengan etika yang baik cenderung menunjukkan moral yang bagus, sedangkan sebaliknya individu yang memiliki etika yang tidak baik maka cenderung akan memiliki moral yang tidak baik. Semakin tinggi penalaran atas moral yang dimiliki seseorang makan akan mengurangi sikap untuk melakukan kecurangan akuntansi (Wilopo, 2006).

Belakangan ini sejumlah LPD di wilayah Tabanan mengalami masalah. LPD Tabanan merupakan salah satu LPD yang mengalami masalah. Ratusan nasabah tidak bisa menarik tabungannya karena kas yang tersisa hanya 60 juta. Menguapnya dana ini, diduga karena diselewengkan oleh oknum pengurus LPD tersebut. Padahal LPD kota Tabanan memiliki nasabah yang cukup banyak, karena mencakup 24 banjar adat yang ada di Desa Pekraman kota Tabanan. Dengan latar belakang yang telah disebutkan diatas maka penelitian yang berkaitan dengan pengaruh pengendalian intern kas, kesesuaian kompensasi dan moralitas individu sangat tertarik untuk dilakukan dengan menggunakan LPD kecamatan Tabanan sebagai objek penelitian. Hasil yang diharapkan dari penelitian ini adalah untuk menjawab apakah terdapat ketimpangan dari perilaku pengurus LPD dari sisi pengendalian intern kas yang mereka lakukan, dan kesesuaian kompensasi yang mereka peroleh serta moralitas masing-masing pengurus
LPD apakah berpengaruh terhadap perilaku yang menyebabkan pengurus LPD melakukan tindakan kecurangan akuntansi (Fraud).

\section{Teori Agensi}

Teori menjelaskan mengenai hubungan pihak principal dengan pihak pelaksana operasional perusahaan (manajemen). Prinsipal memberi kewenangan penuh kepada agen dalam hal teknis pengelolaan perusahaan, sehingga principal tidak boleh ikut mencapuri. Menariknya hubungan antara agen dan prinsipal adalah dalam hal pengawasan dari prinsipal, tidak mungkin hubungan kerjasama ini tidak memiliki masalah. Teori keagenan memiliki tujuan dalam menganalisis serta memperoleh solusi jika terjadi konflik antara kedua pihak tersebut. Individu dalam teori ini akan diasumsikan selalu dapat bertindak untuk kepentingan dirinya. Pihak yang ditunjuk melaksanakan organisasi akan menggunakan wewenangnya untuk dapat memperoleh keuntungan mereka sendiri sehingga kepentingan prinsipal terpinggirkan. Organisasi akan selalu memiliki konflik kepentingan diantara para pihak yang terkait, maka muncullah konflik antar agen. Konflik kepentingan yang berbeda antara agen dan prinsipal tersebutlah yang dapat memunculkan adanya kecendruangan kecurangan akuntansi (fraud). Karena manajemen dengan wewenangnya dapat melakukan hal-hal yang cenderung dapat merugikan perusahaan.

\section{Kecurangan Akuntansi (Fraud)}

Tunggal (2012) mendefinisikan fraud atau kecurangan akuntansi adalah sebuah trik kecurangan yang dilakukan secara terencana dan bermaksud untuk memperoleh keuntungan atau hak seseorang. Ikatan Akuntan Indonesia (IAI, 2012) memberikan definisi atas kecurangan sebagai, pertama penyajian tidak tepat yang timbul atas kecurangan dalam laporan asset dengan tujuan menipu pengguna laporan keuangan, dan kedua kesalahan penyajian yang muncul atas penggunaan yang kurang tepat atas asset sehingga mengakibatkan penyajian laporan berbeda dengan pedoman prinsip akuntansi berlaku umum.

\section{Pengendalian Intern Kas}

Pengendalian intern kas memiliki tuhuan untuk, a) terdapat pemisahan tugas yang dilakukan agar kas dapat lebih terjaga keamanannya dari segala penyelewengan, b) setiap penggunaan kas akan dicatat dan diotoritas dengan baik. Pengendalian intern kas berupaya untuk memperoleh persetujuan atas transaksi yang telah terjadi sehingga dapat dicatat dengan tepat sehingga pelaksana yang ditunjuk dapat mengcroscek setiap informasi tentang transaksi dengan benar, c) menyediakan kas ditangan yang cukup. Kas ditangan yang sesuai 
dapat menyebabkan perusahaan unruk mengatur keuangannya dengan baik, dan d) meminimalisasi kehilang kas. Pengendalian intern kas yang baik akan membantu manajemen dalam pengambilan keputusan.

\section{Kesesuaian Kompensasi}

Kompensasi merupakan imbalan yang diperoleh pegawai sebagai pengganti jasa yang mereka berikan kepada perusahaan (Mondy, 2008). Penggabean (2004) juga memberikan pendapatnya mengenai kompensasi yang merupakan reward kepada karyawan sebagai imbal balik atas jasa yang diberikan kepada perusahaan. Kompensasi bertujuan untuk meningkatkan kerja sama antara pihak principal dan manajemen yang nantinya akan berdampak pada ikatan kerja, stabilitas karyawan dan kepuasan kerja manaemen.

\section{Moralitas Individu}

Moral merupakan sikap maupun tingkah laku yang dimiliki seorang dalam beraktivitas seharihari dan berkaitan dengan orang lain. Moralitas merupakan bagian yang mendasar pada penilaian dari setiap sikap maupun suatu tindakan yang diambil oleh individu. Moralitas individu menjelaskan level penalaran moral individu, yang memiliki pengaruh terhadap tiap perilaku individu (Puspasari, 2012).

\section{Rumusan Hipotesis dan Kerangka} Konseptual

Tunggal (2010) menyatakan bahwa perusahaan-perusaaan yang melaksanakan pengendalin intern dalam perusahaannya akan membantu mereka dengan mudah mengecek adanya kecurangan akuntansi yangterjadi, sehingga mampu mengecek adanya kecurangan sedini mungkin. Apabila perusahaan mempunyai pengedalian intern kas yang kurang memadai hal ini akan memunculkan hambatan dengan adanyaa kesalahan yang akhirnya memberikan informasi akuntansi sebagai hasil dari system akuntansi, yang menyebabkan kualitasnya menjadi tidak baik dan memberikan pengaruh pada ketepatan pengambilan keputusan. System pengendalian intern yang baik dapat memperkecil celah timbulnya kecurangan yang mampu merugikan perusahaan dan menguntungkan bagi si pelaku kecurangan. Husna (2013) menyebutkan pengendalian intern atas kas mampu berpengaruh terhadap upaya pencegahan fraud. Semakin efektif pengendalian intern maka dapat mencegah terjadinya kecenderungan kecurangan akuntansi perusahaan.

H1: Pengendalian Intern Kas memiliki pengaruh negatif terhadap Kecurangan Akuntansi pada LPD Kecamatan Tabanan.

Reward yang diperoleh pegawai merupakan kompensasi atas jasa mereka terhadap perusahaan (Panggabean, 2004). Kompensasi yang diberikan berupa uang dalam bentuk upah, bonus serta tunjangan (Hariandja, 2002). Kompensasi memiliki pengaruh negatif pada fraud (Anggraeni, 2015). Penjelasan diatas dapat terjadi karena kompensasi yang tepat akan memicu karyawan dalam peningkatan kinerja mereka, namun bila kompensasi dirasa tidak sesuai akan membuat karyawan untuk bertindak fraud.

H2: Kompensasi memiliki pengaruh negatif terhadap terjadinya kecurangan akuntansi pada LPD Kecamatan Tabanan.

Penalaran moral setiap individu memiliki level yang berbeda yang mana hal tersebut dipengaruhi oleh perilaku indivisu tersebut (Liyanarachchi dan Newdick, 2009). Individu yang tanpa moral akan dikatakan minus nilai positif dalam dirinya bagi individu lainnya dan akan memungkinkan untuk terjadinya kecurangan. Saputra, Dharmawan, dan Purnawati (2015) menyatakan bahwa MI memiliki pengaruh negatif terhadap terjadinya kecurangan akuntansi. pendapat tersebut karena individu tanpa moral dalam dirinya maka individu itu akan dilihat tidak memiliki hal baik dalam dirinya dan cenderung untuk melakukan kecurangan.

H3: Moralitas Individu memiliki pengaruh negatif terhadap terjadinya kecurangan akuntansi pada LPD Kecamatan Tabanan.

Berdasarkan ketiga rumusan hipotesis tersebut, dibentuklah sebuah kerangka konsep. Selanjutnya akan dijelaskan mengenai kerangka konseptual pada penelitian ini:

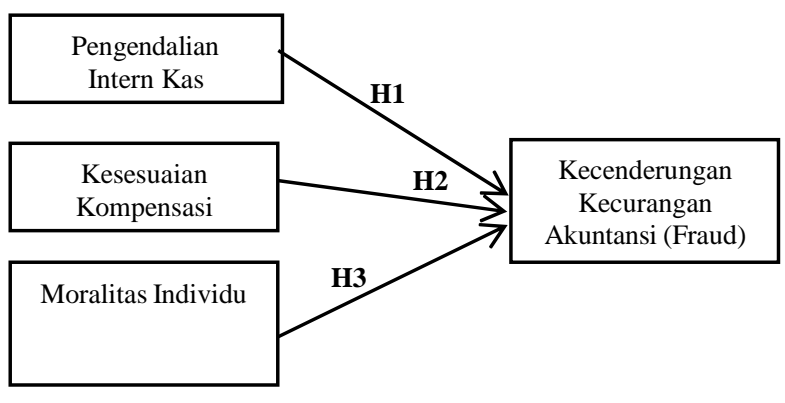

Gambar 1 Kerangka Konseptual Penelitian

Sumber: Penulis

\section{Metode Penelitian}

Lokasi yang digunakan pada penelitian ini adalah LPD yang berada di Kecamatan Tabanan pada tahun 2019. Pengendalian Intern Kas (X1), Kesesuaian Kompensasi (X2) dan Moralitas Individu (X3) merupakan variabel independent yang digunakan pada penelitian ini. Sedangkan 
variabel dependen adalah Kecenderungan Kecurangan Akuntansi (Fraud) (Y). Kuesioner dibuat dengan menampilkan pertanyaan yang menggunakan skala likert dengan 5 opsi skor STS untuk skor 1 , TS untuk skor $2, \mathrm{~N}$ untuk skor $3, \mathrm{~S}$ untuk skor 4 serta SS untuk skor 5 .

\section{Kecenderungan Kecurangan Akuntansi (Fraud)}

Tunggal (2010) mendefinisikan fraud atau kecurangan akuntansi adalah sebuah penggelapan pada sector keuangan yang dilakukan secara sengaja serta bermaksud untuk memiliki asset pihak lain. Sembilan pertanyaan akan digunakan dalam mengukur fraud. Indikator dalam menilai fraud menggambarkan kecenderungan untuk melakukan penyalahgunaan asset, kecenderungan untuk melakukan salah saji material laporan keuangan, dan korupsi.

\section{Pengendaliian Internal Kas (X1)}

Asset lancer berupa kas merupakan hal yang sangat gampang untuk dilakukan penyelewengan. Transaksi kas adalah transaksi peneimaan serta keluarnya kas. Sebab itu agar dapat meminimalisasi adanya kecurangan serta penyelewengan kas diperlukan sebuah sistem internal control yang maksimal atas kas dan bank. Instrumen dalam pengukuran keefektifitasan pada pengendalian internal yaitu sebanyak lima pertanyaan berdasarkan pengembangan pada Seksi 319 IAI, dengan mengadopsi indicator pada COSO (COSO, 2013). Pengendalian intern kas diukur berdasarkan konsep 1) lingkungan pengendalian yang diukur berdasarkan indikator: Komitmen terhadap kompetensi, susunan dewan komisaris, Struktur organisasi, dewan komisaris/komite audit, pelimpahan wewenang dan tanggung jawab; 2) Penetapan resiko yang di ukur berdasarkan indikator: Identifikasi terhadap resiko salah saji laporan keuangan, penetapan resiko yang sesuai dalam penyampaian laporan keuangan sesuai dengan SAK; 3) Aktifitas pengendalian yang dikur berdasarkan indikator: pembagian tugas yang sesuai, otorisasii yang layak terhadap transaksi serta aktivitas, catatan dokumen catatan yang tepat, pengendalian fisik atas kelayakan serta note, adanya penyelidikan independen atas pelaksanaan; 4) adanya info serta komunikasi akuntansi yang diukur berdasarkan indikator: klasifikasi akuntansi, alur informasi akuntansi, prosedur pencatatan dan pelaporan transaksi; 5) Pemantauan diukur berdasarkan indikator: penilaian rancangan dan operasi secara periodik.

\section{Kesesuaian Kompensasi (X2).}

Panggabean (2004) menyatakan bahwa kompensasi merupakan suatu penghargaan untuk pegawai atas jasa kepada organisasi. Kompensasi juga dapat diartikan sebagai balas jasa kepada pegawai atas pelaksanaan pekerjaan mereka pada organisasi berupa upah dalam bentuk gaji, bonus, tunjangan dan lainnya. Pengukuran atas kesesuaian kompensasi dibagi menjadi empat item pertanyaan. Mengakui bahwa perusahaan berhasil dalam melaksanakan pekerjaan, promosi, fasilitas pekerjaan, dan prosedur kompensasi yang mengekpresikan pandangan atas suatu perasaan dan kompensasi keuangan digunakan sebagai indicator pengukuran.

\section{Moralitas Individu (X3)}

Liyanarachchi dan Newdick (2009) menyatakan bahwa level nalar moral dipengaruhi oleh etisnya perilaku seseorang. Individu tanpa moral maka dapat dikatakan tidak memiliki nilai positif sehingga akan dianggap meningkatkan kecurangan. Pengukuran instrumen pada MI ini terdiri dari dua item pertanyaan. Indikator berupa menggambarkan kasus dilematis tingkat moralitas individu.

\section{Teknik Pengumpulan Data}

Penelitian ini menngunakan data primer melalui metode survey dari kuisioner. Jawaban responden atas kuesioner yang diberikan akan dianalisis dengan motode Regresi Berganda yang diolah menggunakan bantuan SPSS. Penelitian ini memiliki populasi berupa seluruh Pegawai LPD di wilayah Kecamatan Tabanan. Sampel penelitian berupa kuantitatif yang merupakan bagian populasi (Sugiyono, 2013). Sampel diambil menggunakan teknik purposive sampling. Penentuan pengambilan sampel dapat dilihat dibawah:

1. LPD di Kecamatan Tabanan yang masuk kategori sehat.

2. Pegawai LPD di Kecamatan Tabanan yang menjadi pengurus LPD.

3. Pegawai LPD di Kecamatan Tabanan yang sudah menjadi pengurus selama satu tahun.

Berdasatkan penentuan sampel diatas diperoleh 36 responden penelitian.

\section{Uji Instrumen Penelitian}

Responden menjadi faktor penentu dalam hasil penelitian ini, dimana dibutuhkan kesungguhan pihak reponden dalam menjawab kuesioner, dimana keabsahan (validitas) akan ditentikan oleh alat ukur dari instrument yang digunakan. Penelitian ini melakukan pengujian mengenai instrumen atas data yang berupa jawaban 
responden. Dimana pengujian tersebut meliputi uji validitas dan uji keandalan.

\section{Analisis Data Uji Asumsi Klasik}

Model pada regresi yang baik seharusnya terbebas dari masalah multikolonieritas, heteroskedastisitas, serta masalah normalitas data, sehingga diperlukan uji atas penggunaan model regresi. Uji asumsi klasik yang digunakan untuk menguji penelitian ini adalah:

\section{Uji Normalitas}

Uji ini akan menggunakan Kolmogrov smirnov, dimana

a. Jika hasil menunjukkan nilai signifikan lebih kecil dan sama dengan 0,05 maka distribusi data dikatakan tidak normal.

b. Jika hasil menunjukkan nilai signifikan lebih besar dari 0,05 maka distribusi data normal

2. Uji Multikolonieritas

Uji ini dilakukan untuk menganalisis matrik korelasi variabel-variabel independen, yang ada pada tolerance value dan nilai VIF. Ukuran tersebut memperlihatkan masing-masing variabel bebas yang dijelaskan oleh variabel bebas lainnya. Cut off berupa nilai tolerance 0,10 atau VIF > 10. Jika VIF $>10$ maka tidak terjadi multikolinearitas.

\section{Uji Heteroskedastisitas}

Uji ini dilakukan untuk mendeteksi terjadinya heteroskedastisitas dengan Uji Glejser. Peregresian varial bebas atas absolute residual merupakan bagian dari uji ini. Model regresi tanpa gejala heteroskedastisitas aklan menujukkan signifikansii variabel bebas terhadap nilai absolut residual statistik di atas $\alpha=0,05$ (Ghozali, 2011).

\section{Analisis regresi linear berganda}

Penggunaan analisis ini untuk melihat hubungan linear diantara lebih variabel independen $(\mathrm{X} 1, \mathrm{X} 2$, X3) dan variabel dependen (Y). Analisi ini diperlukan untuk mengetahui arah hubungan antar variabel independen dan variabel dependen. Persamaan regresi yang digunakan dalam menguji hipotesis keseluruhan pada penelitian ini adalah sebagai berikut:

$\mathrm{Y}=\mathrm{a}+\mathrm{b} 1 \mathrm{X} 1+\mathrm{b}_{2} \mathrm{X}_{2}+\mathrm{b}_{3} \mathrm{X}_{3}+\varepsilon$

Keterangan:

$$
\begin{array}{ll}
\alpha & =\text { Konstanta } \\
\mathrm{b} 1-\mathrm{b} 3 & =\text { Koefisien Regresi } \\
\mathrm{X} 1 \quad & =\text { Pengendalian Intern Kas } \\
\mathrm{X} 2 & =\text { Kesesuaian Kompensasi } \\
\mathrm{X} 3 & =\text { Moralitas Individu } \\
\varepsilon & =\text { Faktor lain yang berpengaruh } \\
\text { terhadap variabel terikat (Y) }
\end{array}
$$

\section{Hasil dan Pembahasan}

Tabel 1 menunjukkan bahwa, pertama nilai minimum dari variabel Pengendalian Intern Kas (X1) adalah 6,44 dan nilai maksimumnya sebesar 19,31. Nilai rata-rata berupa 15,415 menunjukkan bahwa jawaban responden mengarah pada nilai tertinggi, dengan deviation standar adalah 4,288, yang memiliki penjelasan bahwa nilai mean lebih dari standar deviasi, dan menjelaskan adanya indikasi distribusi data yang baik. Kedua, nilai minimum pada variabel Kesesuaian Kompensasi (X2) adalah 7,45 dengan nilai tertinggi sebesar 23,09 . median range sebesar 18,434 menunjukkan secara rata-rata jawaban responden cenderung mengarah ke nilai tertinggi, dengan standar deviasi adalah 5,231, memiliki arti nilai mean diatas standar deviasi, serta teridentifikasi bahwa distribusi datanya bagus. Ketiga, nilai min dari variabel Moralitas Individu (X3) adalah 3,00 serta nilaii maksimumnya 11,55 . Nilai rata-rata yang diperoleh yaitu 9,132 menjelaskan jawaban responden cenderung mengarah pada nilai maksimal, dengan standar deviasi adalah 2,614, memiliki arti bahwa mean diatas standar deviasi, yang teridentifikasi bahwa distribusi data yang bagus. Terakhir, nilai min darivariabel Kecurangan Akuntansi (Fraud) (Y) adalah 5 dengan angka maksimum sebesar 17,63. Nilai rata-rata 8,763 memperlihatkan bahwa jawaban rata-rata responden mengarah pada nilai tertinggi, dengan standar deviasi adalah 4,482, menjelaskan bahwa nilai mean diatas standar deviasi, synag mengindikasikan distribusi data yang baik.

TABEL 1

HASIL UJI STATISTIK DESKRIPTIF

\begin{tabular}{lccccc}
\hline & $\mathrm{N}$ & Min & Max & Mean & St. Dev \\
\hline $\begin{array}{l}\text { Pengendalian } \\
\text { Intern Kas }\left(\mathrm{X}_{1}\right)\end{array}$ & 36 & 6,44 & 19,31 & 15,4150 & 4,28840
\end{tabular}

Y = Kecurangan Akuntansi (Fraud) 


\begin{tabular}{llllll}
$\begin{array}{l}\text { Kesesuaian } \\
\text { Kompensasi } \\
\left(\mathrm{X}_{2}\right)\end{array}$ & 36 & 7,45 & 23,09 & 18,4344 & 5,23176 \\
$\begin{array}{l}\text { Moralitas } \\
\text { Individu (X })\end{array}$ & 36 & 3,00 & 11,55 & 9,1328 & 2,61449 \\
Fraud (Y) & 36 & 5,00 & 17,63 & 8,7631 & 4,48244 \\
$\begin{array}{l}\text { Valid N } \\
\text { (listwise) }\end{array}$ & 36 & & & & \\
\hline
\end{tabular}

Sumber data: diolah

Pengukuran dikatakan valid jika tujuannya nyata dan benar, sebaliknya dikatakan tidak valid apabila hasil atas ukuran menyimpang dari tujuannya. Dasar pengambilan keputusan validitas pada kuesioner jika subnilai pada pearson correlation di masing-masing pertanyaan memperlihatkan nilai di atas 0,3 sehingga data akan dinyatakan valid. Pada tabel 2 menunjukkan koefisien korelasi butir-butir pertanyaan pada atas variabel di kuesioner valid, nilai pearson correlation dapat menunjukkan masing-masing variabel memiliki nilai diatas 0,3 .

TABEL 2

HASIL UJI VALIDITAS

\begin{tabular}{|c|c|c|c|c|}
\hline No & Variabel & Pertanyaan & $\begin{array}{l}\text { Pearson } \\
\text { Correlati } \\
\quad \text { on }\end{array}$ & $\begin{array}{l}\text { Kete- } \\
\text { rangan }\end{array}$ \\
\hline \multirow[t]{5}{*}{1} & \multirow{5}{*}{$\begin{array}{l}\text { Pengendalia } \\
\mathrm{n} \text { Intern } \\
\text { Kas }\left(\mathrm{X}_{1}\right)\end{array}$} & $X_{1 \cdot 1}$ & ,905 & Valid \\
\hline & & $\mathrm{X}_{1.2}$ & ,739 & Valid \\
\hline & & $\mathrm{X}_{1.3}$ & ,882 & Valid \\
\hline & & $\mathrm{X}_{1.4}$ & 893 & Valid \\
\hline & & $\mathrm{X}_{1.5}$ & ,867 & Valid \\
\hline \multirow{6}{*}{2} & \multirow{6}{*}{$\begin{array}{l}\text { Kesesuaian } \\
\text { Kompensas } \\
\mathrm{i}\left(\mathrm{X}_{2}\right)\end{array}$} & $X_{1 \cdot 1}$ &, 871 & Valid \\
\hline & & $\mathrm{X}_{1.2}$ & ,904 & Valid \\
\hline & & $\mathrm{X}_{1.3}$ & ,817 & Valid \\
\hline & & $\mathrm{X}_{1.4}$ & ,924 & Valid \\
\hline & & $\mathrm{X}_{1.5}$ &, 822 & Valid \\
\hline & & $\mathrm{X}_{1.6}$ & ,895 & Valid \\
\hline \multirow{3}{*}{3} & \multirow{3}{*}{$\begin{array}{l}\text { Moralitas } \\
\text { Individu } \\
\left(\mathrm{X}_{3}\right)\end{array}$} & $X_{1 \cdot 1}$ & ,922 & Valid \\
\hline & & $\mathrm{X}_{1.2}$ & ,858 & Valid \\
\hline & & $\mathrm{X}_{1.3}$ &, 832 & Valid \\
\hline \multirow{4}{*}{4} & \multirow{4}{*}{$\begin{array}{l}\text { Kecurangan } \\
\text { Akuntansi } \\
\text { (Fraud) } \\
\text { (Y) }\end{array}$} & $\mathrm{X}_{1 \cdot 1}$ & ,951 & Valid \\
\hline & & $\mathrm{X}_{1.2}$ &, 811 & Valid \\
\hline & & $\mathrm{X}_{1.3}$ &, 894 & Valid \\
\hline & & $\mathrm{X}_{1.4}$ & ,921 & Valid \\
\hline
\end{tabular}

\begin{tabular}{llll}
\hline & $\mathrm{X}_{1.5}$ &, 904 & Valid \\
\hline Sumber: Data diolah & & &
\end{tabular}

Reliabilitas kuesioner pada penelitian ini adalah andal bika jawaban responden atas pertanyaan konsiisten serta stabil setip waktunya. Tingkat reliabilitasp variabel atau instrumen penelitian diperlihatkan pada hasil uji statistik cronbach alpha. Variabel atau instrumen dinyatakan reliabel apabila nilaii cronbach alpha variabel menunjukkan nilai di atas 0,70 .

TABEL 3

\section{HASIL UJI RELIABILITAS}

\begin{tabular}{clcc}
\hline No & \multicolumn{1}{c}{ Variabel } & $\begin{array}{c}\text { Nilai } \\
\text { Cronbach } \\
\text { Alpha }\end{array}$ & Keterangan \\
\hline 1 & $\begin{array}{l}\text { Pengendalian Intern } \\
\text { Kas }\left(\mathrm{X}_{1}\right)\end{array}$ &, 911 & Reliabel \\
2 & $\begin{array}{l}\text { Kesesuaian } \\
\text { Kompensasi }\left(\mathrm{X}_{2}\right)\end{array}$ &, 937 & Reliabel \\
3 & $\begin{array}{l}\text { Moralitas Individu } \\
\left(\mathrm{X}_{3}\right)\end{array}$ &, 841 & Reliabel \\
4 & Fraud $(\mathrm{Y})$ &, 939 & Reliabel \\
\hline
\end{tabular}

Sumber : Data diolah

Uji normalitas digunakan dalam menguji suatu model regresi, apakah variabeli residual mempunyai distribusi normal aatau tidak. Baiknya model regresi dilihat jika memiliki normal distribusi atau mendekati normal. Penelitian ini melakukan pengujian normalitas dengan menggunakan uji statistik Kolmogorov-Smirnov (KS). Data dinyatakan normal apabila koefisien Asymp. Sig (2-tailed) diatas dari nilai sig 0,05 .

TABEL 4

\section{HASIL UJI NORMALITAS}

\begin{tabular}{llr}
\hline & & Unstandardized Residual \\
\hline $\mathrm{N}$ & & 36 \\
Normal Parameters ${ }^{\mathrm{a}, \mathrm{b}}$ & Mean &,- 0626271 \\
& Std. deviation &, 18312473 \\
Most Extreme & Absolute &, 176 \\
$\begin{array}{l}\text { Differences } \\
\end{array}$ & Positive &, 176 \\
& Negative &,- 075 \\
Test Statistic & Mean &, 176 \\
$\begin{array}{l}\text { Asymp. Sig. (2- } \\
\text { tailed) }\end{array}$ & Std. deviation &, 062 \\
& &
\end{tabular}


Sumber: Data diolah

Tabel di atas menunjukkan bahwa nilai Asymp. Sig (2-tailed) sebesar 0,062. Nilai diatas memperlihatkan secara statistikal nilai Asymp. Sig (2-tailed) diatas 0,05 yang berarti data masingmasing variabel yang digunakan dalam penelitian berdistribusi normal.

TABEL 5

HASIL UJI MULTIKOLONIERITAS

\begin{tabular}{lcc}
\hline Model & \multicolumn{2}{c}{ Collinearityi Statisticsi } \\
\hline 1 & Tolerance & VIFi \\
\cline { 2 - 3 } Pengendalian' Intern Kas $\left(\mathrm{X}_{1}\right)$ & 0,906 & 1,104 \\
Kesesuaian' Kompensasi' $\left(\mathrm{X}_{2}\right)$ & 0,888 & 1,127 \\
Moralitas' Individu $\left(\mathrm{X}_{3}\right)$ & & \\
& 0,876 & 1,142
\end{tabular}

Sumber data: diolah

Hasil tabel 5 memperlihatkan bahwa model regresi yang dipergunakan dalam penelitian ini tidak terdapat masalah multikolonieritas. Penunjukan atas adanya nilai tolerance di antara variabel-variabel independen yang diatas 0,10 dan nilai VIF yang lebih kecil dari 10. Uji heteroskedastisitas memiliki tujuan dalammengetes model regresi apakah telah terbentuk ketidaksamaan variance pada residu pengamatan ke pengamatan yang lain. Baiknya model regresi dapat dilihat jika variance pada residual satu pengamatan ke pengamatan lain homokiedastisitas. Metode untuk mendeteksi heteroskedastisitas yaitu menggunakan uji Glejser, dengan sig probabilitas di atas tingkat kepercayaan $(\alpha)=5 \%(0,05)$.

TABEL 6

HASIL UJI HETEROSKEDASTISITAS

\begin{tabular}{lllll}
\hline No & Variabel & $\mathrm{t}$ & Sig. & Keterangan \\
\hline 1 & $\begin{array}{l}\text { Pengendalian } \\
\text { Intern Kas }\left(\mathrm{X}_{1}\right)\end{array}$ &,- 819 &, 419 & $\begin{array}{l}\text { Tidak terjadi } \\
\text { heteroskedastisitas }\end{array}$ \\
2 & $\begin{array}{l}\text { Kesesuaian } \\
\text { Kompensasi }\left(\mathrm{X}_{2}\right)\end{array}$ & $-1,119$ &, 271 & $\begin{array}{l}\text { Tidak terjadi } \\
\text { heteroskedastisitas }\end{array}$ \\
3 & $\begin{array}{l}\text { Moralitas } \\
\text { Individu }\left(\mathrm{X}_{3}\right)\end{array}$ &,- 473 &, 639 & $\begin{array}{l}\text { Tidak terjadi } \\
\text { heteroskedastisitas }\end{array}$ \\
\hline
\end{tabular}

Sumber data: diolah

\section{Analisis Regresi Linear Berganda}

Pengujuan atas 3 hipotesis penelitian ini digunakan analisis regresi linear berganda. Hasil uji regresi linear berganda dapat dilihat padatabel 7 berikut :

TABEL 7

HASIL ANALISIS REGRESI LINIER BERGANDA

\begin{tabular}{cccccc}
\hline Variabel & \multicolumn{2}{c}{$\begin{array}{c}\text { Unstandardized } \\
\text { Coefficient }\end{array}$} & $\begin{array}{c}\text { Standized } \\
\text { Coefficient }\end{array}$ & t & Sig \\
\cline { 2 - 4 } & B & $\begin{array}{c}\text { Std. } \\
\text { Error }\end{array}$ & Beta & & \\
Constant & 28,125 & 1,975 & & 14,240 &, 000 \\
X1 &,- 416 &, 096 &,- 398 & $-4,359$ &, 000 \\
X2 &,- 360 &, 079 &,- 421 & $-4,555$ &, 000 \\
X3 &,- 690 &, 159 &,- 402 & $-4,327$ &, 000 \\
\hline Adjusted Rsquare : $:, 735$ & & & & \\
F hitung & $: 33,373$ & & & & \\
Sig. F hitung & $:, 000$ & & & & \\
\hline
\end{tabular}

Sumber data: diolah

Persamaan regresi:

$\mathrm{Y}=28,125-0,416 \mathrm{X} 1-0,360 \mathrm{X} 2-0,690 \mathrm{X} 3+\varepsilon$

Penjelasan atas persamaan analisis regresi linier berganda adalah senagai berikut, pertama nilai koefisien regresi variabel Pengendalian Internal Kas (X1) sebesar -0,416 dan menunjukkan arah negatif. Hal ini menunjukkan bahwa bila variabel Pengendalian Internal Kas (X1) meningkat sedangkan nilai variabel lainnya tetap, maka variabel Kecurangan Akuntansi (Fraud) akan cenderung menurun sebesar 0,416. Kedua nilaii koefisien regresi variabel Kesesuaian Kompensasi (X2) sebesar -0,360 dan menunjukkan arah negatif. Hal ini berarti apabila variabel Kesesuaian Kompensasi (X2) meningkat sedangkan nilai variabel lainnya tetap, maka variabel Kecurangan Akuntansi (Fraud) akan cenderung menurun sebesar 0,360. Terakhir nilai koefisien regresi variabel Moralitas Individu (X3) sebesar 0,690 dan menunjukkan arah negatif. Hal ini berarti apabila variabel Moralitas Individu (X3) meningkat sedangkan nilai variabel lainnya tetap, maka variabel Kecurangan Akuntansi (Fraud) akan cenderung menurun sebesar 0,690.

\section{Pengujian Hipotesis}

Hipotesis 1 menyatakan pengendalian intern kas memiliki pengaruh negatif atas kecurangan akuntansi pada LPD Kecamatan Tabanan. Berdasarkan Tabel 7, menjelaskan bahwa hasil uji 
t terhadap variabel Pengendalian Intern Kas $\left(\mathrm{X}_{1}\right)$ menunjukkan nilai signifikansi $t$ sebesar 0,000 serta nilai koefisien regresi (B) negatif 0,416. Nilai signifikansi pengendalian intern kas sebesar $0,000<0,05$ sehingga $\mathrm{H} 1$ akan diterima. Penjelasan ini menunjukkan bahwa pengendalian intern kas memiliki pengaruh negatif atas Kecurangan Akuntansi.

Hipotesis 2 menyatakan bahwa kompensasi memiliki negatif atas terjadinya kecurangan akuntansi pada LPD Kecamatan Tabanan. Berdasarkan Tabel 7, menunjukkan mengenai hasil uji $\mathrm{t}$ atas variabel subjective norm $\left(\mathrm{X}_{2}\right)$ diperoleh nilai signifikansi $\mathrm{t}$ sebesar 0,000 dan nilai koefisien regresi (B) negatif 0,360. Nilai signifikansi subjective norm sebesar $0,000<0,05$ sehungga $\mathrm{H} 2$ diterima. Hal ini berarti kompensasi memiliki negatif terhadap kecurangan akuntansi.

Hipotesis ketiga menyebutkan mengenai moralitas individu yang memiliki negatif atas terjadinya kecurangan akuntansi pada LPD Kecamatan Tabanan. Berdasarkan Tabel 7, memperlihatkan mengenai hasil uji t terhadap variabel perceived behavioral control $\left(\mathrm{X}_{3}\right)$ diperoleh nilai signifikansi $\mathrm{t}$ sebesar 0,000 dan nilai koefisien regresi (B) negatif 0,690 . Nilai signifikansi moralitas individu sebesar $0,000<0,05$ sehingga $\mathrm{H}_{3}$ dapat diterima. Hal ini menunjukkan bahwa moralitas individu memiliki pengaruh negartif terhadap kecurangan akuntansi.

Uji $F$ akan diipergunakan dalam pengujian kelayakan model (goodness of fit). Uji F memperlihatkan mengenai semua variabel independen yang dimasukan pada model memiliki pengaruh secara bersama-sama terhadap variabel dependen.

TABEL 8

HASIL UJIF

\begin{tabular}{llrrrr}
\hline Model & $\begin{array}{l}\text { Sum of } \\
\text { Squares }\end{array}$ & df & $\begin{array}{c}\text { Mean } \\
\text { Square }\end{array}$ & F & Sig. \\
\hline 1 Regression & 532,903 & 3 & 177,634 & 33,373 & $0,000^{\mathrm{b}}$ \\
Residual & 170,325 & 32 & 5,323 & & \\
Total & 703,228 & 35 & & & \\
\hline
\end{tabular}

Dependen Variabel: Y

Predictors: (Constant), X3,X1,X2

Sumber data: diolah

Tabel 8 diatas memperlihatkan nilai signifikansi Fhitung sebesar $0,000 \leq 0,05$, hal ini menunjukkan bahwa model regresi layak untuk digunakan. Kesimpulan yang dapt diambil bahwa terdapat pengaruh signifikan secara simultan antara pengendalian internal kas, kesesuaian kompensasi dan moralitas individu kecurangan akuntansi pada LPD Kecamatan Tabanan.

Koefisien determinasi $\left(\mathrm{R}^{2}\right)$ digunakan dalam mengukur sejauh mana kemampuan model untuk menerangkan variasi variabel dependen pada model dapat diterangkan oleh variasi variabel independen (Ghozali, 2016). Analisis ini digunakan untuk mengetahui kemampuan model regresi menjelaskan variasi hubungan antara variabel antara pengendalian internal kas, kesesuaian kompensasi serta moralitas individu terhadap kecurangan akuntansi pada LPD Kecamatan Tabanan.

TABEL 9

HASIL KOEFISIEN DETERMINASI $\left(\mathrm{R}^{2}\right)$

Model Summary

\begin{tabular}{lcrrr}
\hline Model & $\mathrm{R}$ & R Square & $\begin{array}{c}\text { Adjusted } \\
\text { R Square }\end{array}$ & $\begin{array}{c}\text { Std. Error } \\
\text { of the } \\
\text { Estimate }\end{array}$ \\
\hline 1 & $0,871^{\text {a }}$ & 0,758 & 0,735 & 2,30709
\end{tabular}

Berdasarkan Tabel 9, memperlihatkan bahwa nilai adjusted R Square sebesar 0,735 atau sebesar $73,5 \%$. Artinya sebesar $73,5 \%$ variasi kecurangan akuntansi dipengaruhi oleh model yang dibentuk oleh variabel pengendalian nternal, kesesuaian kompensasi dan moralitas individu pada LPD Kecamatan Tabanan sedangkan sisanya sebesar 26,5\% dijelaskan oleh variabel lainnya yang tidak ada dalam penelitian ini.

\section{Pembahasan Hasil Penelitian}

Berdasarkan pengujian menunjukkan bahwa hipotesis pertama menunjukkan bahwa pengendalian internal kas memiliki pengaruh negatif atas kecurangan akuntansii. Temuan tersebut membuktikan jika tingkat efektifitas pengendalian internal kas baik menyebabkan kecurangan akuntansi akan menurun.

Penelitin ini memperoleh hasil yang mendukung penelitian terdahulu dari Zainal (2013), yang menjelaskan mengenai kecenderungan kecurangan akuntansi bisa diminimalisasi apabila terdapat sistem pengendalian internal yang baik yang dapat diterapkan oleh perusahaan. Baiknya sistem pengendalian internal yang diterapkan akan menurunkan kecenderungan atas kecurangan 
akuntansi. Hasil tersebut juga didukung oleh penelitian Udayani dan Sari (2017) yaitu dengan digunakannya system pengendalian internal yang tepat maka akan mengantisipasi penyimpangan oleh pihak manajemen pada system pelaporan termasuk kecurangan akuntansi.

Hasil pengujian hipotesis kedua menunjukkan jika kesesuaian kompensasi memiliki pengaruh negatif atas kecurangan akuntansi. Penjelasan tersebut membuktikan bahwa semakin sesuai penerimaan kompensasi karyawan sehingga akan menurunkan tingkat kecurangan akuntansi. Kompensasi atau bonus yang diterima karyawan menyebabkan karyawan akan bertanggung jawab dengan baik atas penyampaian laporan keuangan, sehingga akan menurunkan kecurangan akuntansi.

Hasil tersebut sejakur dengan hasil penelitian oleh Zilmy (2013) dimana pembayaran kompensasi pada pemerintahan yang bagus, tetapi terlihat bahwa kompensasi yang telah diberikan kepada pegawai tidak cukup adil sehingga menyebabkan timbulnya kecenderungan kecurangan akuntansi. Kompensasi sebaiknya diberikan setara dengan kontribusi jasa yang dilakukan karyawan. Penyerahan kompensasi yang tepat dapat meningkatkan kepuasan serta motivasi dalam bekerja sehingga kecurangan akuntansi tidak terjadi (Radhiah, 2016).

Berdasarkan pengujian terhadap hipotesis ketiga ditemukan mengenai moralitas individu memiliki pengaruh negatif akan kecurangan akuntansi. Moralitas merupakan suatu sifat moral serta nilai yang terkait dengan perilaku baik dan buruk (Dewi, 2014). Seseorang yang memiliki level penalaran moral rendah akan cenderung memiliki sikap yang berbeda dengan seseotang yang memiliki level penalaran moral yang tinggi ketika dihadapkan dengan dilema etika. Tingginya level penalaran moral seseorang, meyebabkan orang tersebut akan lebih memungkinkan dalam melaksanakan 'hal yang benar'

Penelitian ini memiliki hasil yang konsisten dengan penelitian terdahulu seperti oleh Friskila (2010) dan Nani (2010) diaman jika moral seorang manajemen atau pegawai rendah, ia akan cenderung untuk melakukan tindakan yang dapat merugikan perusahaan, sehingga untuk menutupi hal yang telah mereka lakukan akan dilakukan Tindakan manipulative atas data dalam laporan keuangan, dimana Yuliana (2015) juga menemukan hasil yang sama.

\section{Simpulan}

Kesimpulan yang diperoleh dari penelitian ini adalah:
1. Pengendalian internal kas memiliki pengaruh negatif atas kecurangan akuntansi. penjelasan yang dapat menunjukkan hal tersebut adalah semakin efektifnya tingkat pengendalian internal kas pada LPD akan meminimalisasi tingkat curang pada akuntansi.

2. Kesesuaian akuntansi memiliki pengaruh negative terhadap kecurangan akuntansi. Dimana ditemukan hasil bahwa kompensasi atau bonus yang diterima karyawan akan menyebabkan mereka memiliki rasa tanggung jawab besar akan laporan keuangan yang mereka sajikan dan akhirnya akan berdampak pada penurunan kecurangan akuntansi.

3. Moralitas individu memiliki pengaruh negatif atas kecurangan akuntansi. Hal yang dapat dijelaskan mengenai hal tersebut bahwa pribadi dengan level penalaran moral yang rendah memiliki perilaku berbeda dengan orang yang memiliki level penalaran moral yang tinggi ketika menghadapi dilema etika.

\section{Saran}

Saran yang dapat diberikan untuk pengembangan dari penelitian ini adalah:

1. Pihak LPD di Kecamatan Tabanan sebaiknya melakukan pengaturan atas pengendalian internal pada organisasi mereka untuk mendapatkan kendali dalam proses organisasi mereka.

2. Pihak LPD di Kecamatan Tabanan sebaiknya dapat memberikan kompensasi yang sesuai dengan hasil kerja karyawan sehingga kecurangan akuntansi akan menurun.

3. LPD di Kecamatan Tabanan menyeleksi individu yang memiliki moralitas baik, agar kedepannya dapat mengurangi kecurangan. Selain itu penelitian kedepannya dapat menambahkan variabel independen serta memperluas sampel penelitian.

\section{Referensi}

A. Anggraeni, Lusia Shinta (2015). Pengaruh Produktivitas, Efisiensi, Kepuasan kerja Terhadap Perputaran Karyawan Bagian Marketing. Jurnal Ilmu dan Riset Manajemen, Vol 4. (5). 3 \& 9.

B. Bartenputra, Adrian. 2016. Pengaruh Kesesuaian Kompensasi, Ketaatan Akuntansi, dan Asimetri Informasi Terhadap Kecendrungan Kecurangan Akuntansi.

C. COSO, 2013. Internal Control - Integrated Framework. Diakses 21 Januari 2020, http://www.coso.org/

D. Dewi, Gusti Ayu. 2014. Pengaruh Moralitas Individu dan Pengendalian Internal Terhadap Kecenderungan 
Kecurangan Akuntansi: Studi Eksperimen Pada Pemerintah Daerah Provinsi Bali. Tesis: Program Pasca Sarjana. Universitas Udayana.

E. Friskila, M. 2010. Pengaruh Ketaatan Akuntansi, Sistem Pengendalian Intern, Moralitas Manajemen dan Kesesuaian Kompensasi Terhadap Kecenderungan Kecurangan Akuntansi (Studi empiris pada Perusahaan BUMN di Kota Padang). FE UNP: Padang

F. Ghozali, Imam. 2011. Aplikasi Analisis Multivariate Dengan Program SPSS. Semarang: Badan Penerbit Universitas Diponegoro.

G. Ghozali, Imam. 2016. Aplikasi Analisis Multivariate Dengan Program IBM SPSS 23 (Edisi 8). Cetakan ke VIII. Semarang: Badan Penerbit Universitas Diponegoro

H. Hariandja, Marihat Tua Efendi, 2002, Manajemen Sumber Daya Manusia, Grasindo, Jakarta

I. Husna, Fitriatil. 2013. Pengaruh Penerapan Pengendalian Intern Kas dan Implementasi Good Corporate Governance Terhadap Kecurangan (Studi Empiris Pada Perusahaan BUMN di Kota Padang). Skripsi. Universitas Negeri Padang, Padang.

J. Ikatan Akuntansi Indonesia. 2012. Standar Akuntansi Keuangan. Jakarta: Salemba Empat

K. Liyanarachchi, G dan Newdick, C. 2009. The Impact of Moral Reasoning and Retaliation on Whistle-Blowing: New Zealand Evidance. Journal of Business Ethics, 89:37-57.

L. Nani, W. 2010. Pengaruh Moralitas, Motivasi dan Sistem Pengendalian Intern Aparatur Pemerintah Tehadap Tingkat Kecurangan dalam Laporan Keuangan Pemerintah Kota Padang. Skripsi. Universitas Negeri Padang

M. Meliany, Lia dan Hernawati, Erna, 2013, Pengaruh Keefektifan Pengendalian Internal Dan Kesesuaian Kompensasi Terhadap Kecenderungan Kecurangan Akuntansi. Jurnal \& Proceeding FED UnSoed Vol 3 No. 12013.

N. Mondy, R. Wayne. 2008. Manajemen Sumber Daya Manusia. Jilid Satu Edisi Sepuluh. Jakarta: Erlangga.

O.Panggabean, S.M., 2004. Manajemen Sumber Daya Manusia. Bogor: Ghalia Indonesia

P. Puspasari \& Suwardi. 2012. Pengaruh Moralitas Individu dan Pengendalian Internal terhadap Kecenderungan Kecurangan Akuntansi. Jurnal Universitas Gadjah Mada.
Q. Radhiah, T. 2016. Pengaruh Efektifitas Pengendalian Internal, Kesesuaian Kompensasi dan Moralitas Individu terhadap Kecenderungan Kecurangan Akuntansi (Studi Kasus pada PT. POS Indonesia KCU Kota Pekanbaru). JOM Fekom, Vol. 3 No. 1 Hal: 1-12

R. Rahyuda, Ketut. 2017. Metode Penelitian Bisnis, Udayana University Press, Denpasar.

S. Randiza, Ichsan 2016, Pengaruh Pengendalian Internal, Asimetri Informasi, Moralitas Aparat Pemerintah dan Ketaatan Aturan terhadap Kecenderungan Kecurangan Akuntansi (Studi Kasus pada SKPD Kab. Indragiri Hilir). Jurnal Online Mahasiswa Fakultas Ekonomi

T. Saputra, Gede Krisna, dkk. 2015. Pengaruh Pengendalian Intern Kas, Implementasi Good Governance dan Moralitas Individu Terhadap Kecurangan (Fraud).

U. Sugiyono. 2013. Metode Penelitian Kuantitatif, Kualitatif dan R\&D. Bandung: Alfabeta.CV

V. Thoyibatun, Siti. 2009. Faktor-Faktor yang Berpengaruh terhadap Perilaku Tidak Etis dan Kecenderungan Kecurangan Akuntansi serta Akibatnya terhadap Kinerja Organisasi. Jurnal Universitas Negeri Malang

W. Tunggal, A. W. 2010. Dasar-dasar Audit Intern Pedoman untuk Auditor baru. Jakarta: Harvarindo.

X. Tunggal, A. W. 2012. Intisari Internal Auditing, Harvarindo, Jakarta, 2012, Hal. 70

Y.Udayani dan Sari. 2017. Pengaruh Pengendalian Internal Dan Moralitas Individu Pada Kecenderungan Kecurangan Akuntansi. E-Jurnal Akuntansi Universitas Udayana. Vol.18.3. Maret (2017): 1774-1799.

Z. Wilopo. 2006. Analisis Faktor-Faktor yang Berpengaruh Terhadap Kecenderungan Kecurangan Akuntansi: Studi pada Perusahaan Publik dan Badan Usaha Milik Negara (BUMN) di Indonesia. Jurnal Riset Akuntansi Indonesia vol. 9

AA. Yuliana, E. 2015. Pengaruh Moralitas Individu dan Sistem Pengendalian Internal terhadap Kecenderungan Kecurangan Akuntansi. Jurnal Akuntansi Vol 4 No. 1 Oktober 2015

BB. Zainal, Rizki. 2013. Pengaruh Efektivitas Pengendalian Intern, Asimetri Informasi Dan Kesesuaian Kompensasi Terhadap Kecenderungan Kecurangan Akuntansi (Fraud). Jurusan Akuntansi Fakultas 
Ekonomi Universitas Negeri Padang.

Padang

CC. Zilmy, R.P. 2013. Pengaruh Kesesuaian Kompensasi, Asimetri Informasi dan Moralitas Terhadap Kecenderungan Kecurangan Akuntansi (Studi Empiris pada Satuan Kerja Perangkat Kota Daerah Padang). Jurnal UNP: Padang 